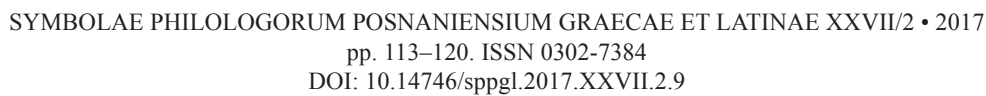

MARIOLA WALCZAK-MIKOŁAJCZAKOWA

Uniwersytet im. Adama Mickiewicza w Poznaniu

\title{
BUŁGARSKIE PRZEKŁADY BAJEK EZOPA I ICH ROLA W KSZTAŁTOWANIU ODRODZONEGO SPOŁECZEŃSTWA W XIX WIEKU
}

\begin{abstract}
Walczak-Mikołajczakowa Mariola, Bułgarskie przekłady bajek Ezopa i ich rola w kształtowaniu odrodzonego spoleczeństwa w XIX wieku (Bulgarian Translations of Ezop's Fairy Tales and Their Role in Shaping a Revived Society in $19^{\text {th }}$ century).

The article considers the Bulgarian translations of Aesop's fairy tales done in the nineteenth century. Then they occupied an important place in the textbooks for the newly emerging secular schools. As a popular reading, they also played an important role in the discussion on normalization of the Bulgarian language.
\end{abstract}

Keywords: Aesop's fairy tales; translations into Bulgarian; national revival.

Wydawać by się mogło, że ze względu na bliskość geograficzną i kulturową Grecji oraz Bułgarii, przede wszystkim zaś ze względu na ożywione kontakty piśmiennicze i ważną rolę, jaką język grecki odgrywał przez wiele stuleci na Bałkanach, twórczość Ezopa powinna być znana bułgarskiemu odbiorcy bardzo wcześnie. Przyjęcie przez chana Borysa chrztu z Konstantynopola w 864 r. na trwałe związało Bułgarię z grecko-bizantyńskim kręgiem kulturowym. Przez niemal tysiąc lat piśmiennictwo bułgarskie starało się naśladować wzorce bizantyńskie, stąd często po prostu tłumaczono dzieła spisane w języku greckim. Po zajęciu Bałkanów przez osmańskich Turków w XV wieku, greka stała się językiem bułgarskiej Cerkwi i przyklasztornych szkół, wypierając stamtąd język cerkiewnosłowiański. Trwające przez pięćset lat panowanie tureckie stworzyło językowi greckiemu idealne warunki do tego, by stał się on językiem handlu i rzemiosła, a także idiomem ludzi wykształconych. Bilingwizm, a nawet trójjęzyczność w całym imperium osmańskim były zjawiskiem powszechnym ${ }^{1}$. By zdać sobie sprawę z tego, z jaką siłą greka oddziaływała na język bułgarski, wystarczy wspomnieć, że to właśnie pod wpływem języka greckiego wykształciły się w bułgarszczyźnie rodzajniki i inne cechy gramatyczne właściwe językom ligi bałkańskiej².

${ }^{1}$ Nikolova 2006.

${ }^{2}$ Przemożny wpływ greki na inne języki używane na Bałkanach był jednym z powodów ukształtowania się tzw. bałkańskiej ligi językowej, czyli grupy języków bliżej niespokrewnionych 
Tymczasem w odniesieniu do greckiej literatury antycznej rzecz ma się zgoła inaczej - pozostawała ona dla Bułgarów nieznana. Nie powinno zatem dziwić, że pierwsze thumaczenia bajek Ezopa powstały dopiero na początku XIX wieku i długo pozostawały w postaci rękopiśmiennej. Dopiero wydanie w 1824 r. książki Petyra Berona popularnie nazywanej Elementarzem z ryba (był to pierwszy podręcznik dla powstających wówczas szkół świeckich) spowodowało, że do rąk bułgarskiego odbiorcy mogło trafić pierwszych 18 bajek greckiego autora.

W tym miejscu przypomnieć należy, że w Polsce miało to miejsce kilka wieków wcześniej - wątki bajkowe pojawiły się już w średniowieczu, w exemplach używanych przez kaznodziejów i kronikarzy, a w XVI wieku powstały dwa zbiory bajek: poetycki Biernata z Lublina (Żywot Ezopa Fryga... z przypowieściami jego) oraz prozaiczny nieznanego autora (Fabuly Ezopowe albo przypowieści).

Tymczasem - jak już zostało powiedziane - bajki Ezopa nie były w Bułgarii znane do początku XIX wieku, nie rozwijało się także bajkopisarstwo33. Nic w tym zresztą dziwnego, gdyż literacka epoka średniowiecza trwała tam do końca XVIII stulecia, a bułgarskie średniowiecze nie było zainteresowane kulturą antyczną. Średniowieczni twórcy wzorowali się na piśmiennictwie bizantyjskim - tłumaczono z greki dzieła pisarzy bizantyjskich, a w utworach oryginalnych naśladowano ich wykwintny styl, który przeszedł do historii pod nazwą ,splatania słów".

Za pośrednictwem tłumaczonych na cerkiewszczyznę bizantyńskich kronik trafiły do bułgarskich odbiorców jedynie opowieści o wojnie trojańskiej i legendy o Aleksandrze Wielkim, obecne już w XIV-wiecznych rękopisach słowiańskich. Na Bałkany dotarła też biografia Ezopa zatytułowana Слово прэмљдраго ижсъпа како бысть житие его (Stowo madrego Ezopa o tym, jakie było jego $\dot{z} y(i e)^{4}$. Jej autorstwo przypisuje się Maksymowi Planudesowi, bizantyńskiemu thumaczowi i filologowi z XIII wieku. Opowieść o greckim bajkopisarzu została przetłumaczona w wieku XVI na język cerkiewnosłowiański, utrzymujący się w Bułgarii w roli języka piśmiennictwa do połowy wieku XIX. W anegdotycznej formie zostało w niej przedstawione życie Ezopa, głuchoniemego niewolnika, który odzyskawszy mowę chwali się swemu panu, że wie wszystko o wszystkim. Dzięki mądrości i przebiegłości bohater tej opowieści wychodzi cało $\mathrm{z}$ wielu opresji, ratuje także przed niebezpieczeństwami swego pana, a ten w nagrodę czyni go nauczycielem swoich dzieci. W końcu jednak Ezop, fałszywie oskarżony przez swoich wychowanków, zostaje skazany na śmierć. Wydaje się, że to niewielkie bizantyńskie dziełko mogło zwrócić uwagę słowiańskiego

genetycznie, które w procesie konwergencji wykształciły pewne wspólne cechy gramatyczne. Do ligi bałkańskiej należy język grecki, bułgarski, macedoński, rumuński i albański.

${ }^{3}$ Pewien wyjątek stanowiła tu twórczość pisarzy katolickich, ale ich utwory przeznaczone były dla wyjątkowo wąskiej i odizolowanej od reszty społeczeństwa mniejszości wyznaniowej.

${ }^{4}$ Fragmenty tej opowieści ukazały się w przekładzie na język polski w antologii dawnej prozy bułgarskiej pod red. Teresy Dąbek-Wirgowej (Siedem niebios i ziemia,Warszawa 1983). 
tłumacza, gdyż przypowieści o charakterze baśniowym w XVI wieku powoli zaczynały w Bułgarii zyskiwać na popularności. Działo się to jednak nie pod wpływem wzorców greckich lecz turecko-arabskich ${ }^{5}$.

$\mathrm{Na}$ brak zainteresowania kulturą antycznej Grecji wpłynęło wiele czynników. Nie sposób w krótkim szkicu omówić wyjątkowo skomplikowany stosunek Bułgarów do wszystkiego, co greckie (swój moment kulminacyjny dyskusje nad tym problemem osiągnęły w XIX wieku, czyli w epoce odrodzenia narodowego), wystarczy jedynie przypomnieć, że wedle słów Paisija Chilendarskiego ${ }^{6}$ „historia Bułgarii jest historią wojen z Grekami”. Rzecz jasna Paisij ma tu na myśli Bizancjum - największego wroga państwa bułgarskiego od czasów jego powstania pod wodzą protobułgarskiego chana Asparucha (681 r.) aż do upadku tzw. drugiego carstwa w roku 1396.

Na wyjątkowo niechętny stosunek Bułgarów do Greków wpłynął też fakt, że w okresie niewoli tureckiej zwierzchnikiem i reprezentantem całego „narodu chrześcijańskiego" w państwie Osmanów był patriarcha Konstantynopola, któremu podporządkowano Kościoły lokalne. W ten sposób chrześcijanie w Turcji, niezależnie od pochodzenia, stali się Romejami, czyli Grekami ${ }^{7}$. Przez kilka wieków zatem, Bułgarzy chcący zdobyć wykształcenie musieli swą edukację zaczynać w tzw. metochach, czyli szkołach przyklasztornych z greckim językiem nauczania, co wprawdzie rozszerzało znajomość tego języka i umiejętność posługiwania się nim w mowie i piśmie ${ }^{8}$, ale nie przekładało się na zainteresowanie kulturą grecką.

Wzrost zainteresowania nastąpił dopiero pod koniec wieku XVIII i przybrał na sile w wieku XIX, epoce intensywnych przemian społecznych, okresie tworzenia świeckiego systemu oświaty, w którym słowo Grek (bułg. грък) funkcjonowało nie tyle jako etnonim, ile jako potoczne określenie mieszczanina, rozpoznawanego po greckim (czyli miejskim, nie chłopskim) ubiorze. Pisze o tym krakowska badaczka tego fenomenu, Elżbieta Solak:

Określenia Hellen, helleński traktowane są jako afirmacja poglądów i przedsięwzięć związanych z modernizacją kultury języka greckiego w duchu europejskiego Oświecenia. W kontekście bałkańskim są znakiem przynależności do wykształconej na zachodzie Europy greckiej elity intelektualnej. Jako Hellenowie identyfikowali się też wychowankowie zreformowanych

${ }^{5}$ Dinekov 1990: 197.

${ }^{6}$ Historia stowianobutgarska (1762) Paisija Chilendarskiego zapoczątkowała ferment intelektualny, który rozpoczął proces kształtowania się bułgarskiej tożsamości narodowej, a z czasem doprowadził do rozwoju myśli narodowowyzwoleńczej.

${ }^{7}$ Solak 2009: 243.

${ }^{8} \mathrm{~W}$ środowisku oświeconych Bułgarów korespondencja w języku greckim była zjawiskiem normalnym i powszechnym. W tym języku pisali listy nawet najwybitniejsi działacze bułgarskiego odrodzenia, nazywani budzicielami narodowymi, m.in. krytykujący grekomanię niektórych swoich rodaków Wasyl Apiłow (znane są np. jego listy po grecku pisane do autora pierwszej bułgarskiej gramatyki, Neofita Rylskiego). 
w duchu Oświecenia szkół greckich, niezależnie od przynależności etnicznej, a więc pochodzenia na przykład bułgarskiego, wołoskiego czy albańskiego. Neohellenizm, postrzegany jako elitarna kultura miejska, był więc w pewnym sensie antytezą kategoryzacji (i identyfikacji) etnicznej. Była to kultura języka greckiego, w sferze obyczajowej oparta na systemie wartości i wzorcach charakterystycznych dla burżuazji zachodnioeuropejskiej (głównie francuskiej) ${ }^{9}$.

„Helleńskie” - czy też „helleno-bułgarskie”, jak je nazywano - szkoły zaczęły powstawać w połowie XIX w. coraz liczniej. Z myślą o nich pisano też podręczniki, w których trwałe miejsce - jako element kultury europejskiej znajdowały kolejne przekłady bajek Ezopa. Elżbieta Solak pisze: „Mimo deklarowanego przez część środowisk patriotycznych antyhellenizmu i programowej «nienawiści do wszystkiego, co greckie», grecka szkoła jest synonimem dobrego wykształcenia, a określenie grecki konotuje europejskość, kulturę, obycie""10.

W pierwszej połowie XIX wieku przekłady z nowożytnej greki stanowiły dużą część tekstów (zarówno tych, które pozostały w rękopisach, jak i tych, które zostały wydane), co po części wynikało z faktu, że literatura bizantyńska stanowiła tradycyjne zaplecze literatury religijnej. Tłumaczenia utworów antycznych nadal czekały na swoją kolej.

Pierwszego przekładu bajek Ezopa - wciąż jeszcze na mieszankę cerkiewnosłowiańskiego z bułgarskimi elementami gwarowymi - dokonał ok. 1802 r. biskup Wracy, Sofroniusz ${ }^{11}$; pozostał on jednak w formie rękopisu. Sofroniusz (znany przede wszystkim jako autor pierwszej na gruncie bułgarskim autobiograficznej książki Życie i cierpienia grzesznego Sofroniusza) przełożył aż 144 bajki. Przekładu dokonał jednak nie z antycznej greki, lecz z nowogreckiego thumaczenia autorstwa Joanisa Patusasa (Wenecja 1752), a być może nawet uczynił to, wzorując się na przekładzie serbskim Dositeja Obradovicia. Warto nadmienić, że oba te przekłady różnią się znacznie od starogreckiego oryginału. Nowogrecką wersję cechował uproszczony, szczególnie pod względem składniowym, język, w wielu miejscach przypominający mowę potoczną ${ }^{12}$. Taki jest też język Sofroniuszowego tłumaczenia. Oprócz tego wersja Patusasa, a w ślad za nią bułgarski przekład, zawierają swoiste uwspółcześnienia antycznego tekstu, np. poprzez wprowadzenie pojęć z zakresu filozofii i religii zrozumiałych dla czytelnika z nowej epoki, a także zastąpienia imion wielu bogów Bogiem chrześcijańskim ${ }^{13}$. Ponadto Sofroniusz nie czuł się niewolnikiem greckiego tekstu - zdarzało mu się na przykład uzupełnianie treści o wyjaśnienia (związane

\footnotetext{
${ }^{9}$ Solak 2009: 239-240.

${ }^{10}$ Solak 2009: 240.

${ }^{11}$ Warto zaznaczyć, że Sofroniusz jest też autorem Nedelnika, uznawanego za pierwszą bułgarską książkę (1806). W istocie Nedelnik sireč Kiriakodromion jest przeróbką wcześniejszego thumaczenia cyklu kazań Agapiusza Kreteńczyka (XVII w.). Zob. Solak 2009: 241.

${ }^{12}$ Ničev 1963: 35-37.

${ }^{13}$ Walczak-Mikołajczakowa 2009: 22-27.
} 
np. ze sposobem oddawania czci bogom) jego zdaniem niezbędne dla zrozumienia bajki. Najważniejszą zmianą w stosunku do starogreckiego oryginału jest wzorowane na wersji nowogreckiej rozszerzanie treści bajek, szczególnie zaś kończących je wniosków dydaktycznych. Morały u Sofroniusza były tak rozwinięte, by odbijała się w nich etyka chrześcijańska. Sofroniuszowi przyświecały bowiem przede wszystkim dydaktyczno-moralizatorskie cele.

Podobny, zarówno pod względem treści jak i języka, łączącego cerkiewnosłowiański z bułgarszczyzną ludową, jest anonimowy przekład z 1812 roku, zawierający 120 bajek. Wprawdzie nie zdobył on nigdy popularności, ale za to ze względu na charakterystyczny zapis w postaci równoległego tekstu greckiego i bułgarskiego (umieszczonych w dwóch kolumnach), stanowi doskonałe źródło do badań porównawczych. Jego podstawą był zresztą ten sam, co w przypadku Sofroniusza tekst nowogrecki Joanisa Patusasa.

Szeroką popularność zyskały natomiast bajki zamieszczone we wspomnianym wyżej Elementarzu z ryba Petyra Berona (1824). Dla historii języka bułgarskiego mają one szczególne znaczenie - Elementarz jest bowiem, co podkreśla wielu językoznawców, pierwszą książką napisaną żywym ludowym językiem. Wielokrotnie wznawiany, niezwykle chętnie czytany (nie tylko w szkołach i nie tylko przez uczniów) Elementarz wywarł na czytelników ogromny wpływ. Beron zamieścił w swoim podręczniku zaledwie 18 bajek, które opatrzył tytułami, stanowiącymi jednocześnie płynący z nich morał. Ich dydaktyczna treść została więc wysunięta na pierwszy plan. Dla Berona bajki Ezopa nie stanowiły tekstów „kanonicznych”, traktował je jedynie jako tworzywo, które, odpowiednio przerobione, mogło stanowić podstawę nowego moralizatorsko-dydaktycznego tekstu. Treści zostały też - $\mathrm{z}$ uwagi na odbiorcę, jakim miały być dzieci - odpowiednio skrócone i przystosowane do dziecięcej wrażliwości. Bułgarski tłumacz i adaptator korzystał tym razem najprawdopodobniej z rumuńskich przekładów Ezopa, w których ezopowe treści zostały tak przerobione, by wyraźnie podkreślić ich przesłanie dydaktyczne i stawały się nierzadko swoistym apelem do młodych przedstawicieli odradzającego się społeczeństwa. Trafiały jednak w gusta młodych, którzy po raz pierwszy mieli okazję zetknąć się z tekstami innymi niż religijne. Dodajmy, że oprócz bajek Ezopa Beron zamieścił w swoim podręczniku 10-stronicowy rozdział zatytułowany Mądre odpowiedzi (Умни ответи). Zawierał on 64 króciutkie pouczające przypowieści oparte na wydarzeniach z życia greckich filozofów, które znakomicie charakteryzują ówczesne metody nauczania etyki i zapoznawania z podstawami kultury europejskiej ${ }^{14}$. Dla zilustrowania tej tezy przytoczmy kilka z nich:

\footnotetext{
${ }^{14}$ Mądre odpowiedzi są również przekładem tekstu nowogreckiego, inspirowanego zapewne Żywotami i poglądami stynnych filozofów Diogenesa Laertiosa (I poł. III w.) lub Wypisami, wypowiedziami i naukami Stobajosa (V w.).
} 
1. Zapytano Talesa: Co jest trudne? A on odpowiedział: Trudno jest poznać samego siebie. Spytano go ponownie: A co jest łatwe? On wtedy rzekł: Uczyć innych.

4. Zapytano Epikteta: Kto jest bogaty? Odpowiedział: Ten, kto jest wdzięczny za to, co ma.

13. Powiedziano Sokratesowi, że ktoś o nim źle mówi, a on na to: Nie dziwcie się, przecież on nie potrafi mówić dobrze.

29. Zapytano Platona: Jaka jest różnica między człowiekiem wykształconym i niewykształconym. A ten odpowiedział: Taka jak między lekarzem i chorym ${ }^{15}$.

Popularność przekładów Berona brała się również (a może przede wszystkim) z przystępności języka, jakim zostały spisane. Język Elementarza był jednym z najważniejszych ogniw trwającego wówczas łańcucha zmian w procesie normalizacji nowobułgarskiego języka literackiego, opartego w większej mierze na żywej bułgarszczyźnie mówionej niż na wzorcach literackich z minionych epok. Wydanie tej właśnie książki zapoczątkowało ożywioną, trwającą kilkadziesiąt lat dyskusję na temat tego, co to znaczy „pisać tak, jak się mówi”" Ostateczna normalizacja języka nowobułgarskiego nastąpiła dopiero po wyzwoleniu, czyli po roku 1878.

Najwyraźniej jednak teksty tego rodzaju były młodym Bułgarom bardzo potrzebne, gdyż bajki Ezopa szybko stały się ich ulubioną lekturą. O popularności, jaką zdobyły bajki w połowie XIX wieku świadczyć mogą zachowane z tamtych czasów dokumenty - np. potwierdzenie zakupu i odbioru książek, podpisane 18 listopada 1854 r. w Belgradzie przez niejakiego Najdena Chadżijowanowicza. Wśród zakupionych przez niego tomów najliczniej reprezentowana była Biblia, zaś bajki Ezopa znalazły się na drugim miejscu ${ }^{17}$. Bajki Ezopa były więc najpowszechniej znanymi dziełami antycznymi w Bułgarii epoki odrodzenia. Uczono o nich w szkołach, nierzadkie były też przypadki ich folkloryzowania. W drugiej połowie XIX wieku pojawiły się ich obszerne wydania drukiem ${ }^{18}$.

Zanim to jednak nastąpiło, przekładem bajek zajęli się Naeofit Bozweli i Emanuel Waskidowicz, autorzy kolejnego niezwykle popularnego podręcznika, wydanego w serbskim Kragujewcu w 1835 r. i zatytułowanego Славеноболгарское детоводство (со mоżna przetłumaczyć jako Stowianobutgarskie wychowanie dzieci). Książka ta, podobnie jak Elementarz z ryba, miała charakter encyklopedyczny, a oprócz tekstów literackich zawierała także najróżniejsze przydatne w życiu wskazówki i porady oraz podstawowe wiadomości z zakresu gramatyki języka bułgarskiego, matematyki, geografii i innych dziedzin nauki. Warto w tym miejscu zwrócić uwagę na sylwetki jej autorów.

Archimandryta Neofit, który przeszedł do historii pod pseudonimem Bozweli, był jedną z najważniejszych postaci bułgarskiego odrodzenia narodowego.

\footnotetext{
${ }^{15}$ Beron 1824: 41-51; przeł. M. W-M.

${ }^{16}$ Było to jedno z naczelnych haseł zwolenników reformy języka piśmiennictwa. Jego autorem jest wspomniany Wasyl Apriłow.

${ }^{17}$ Aretov 1995: 3.

${ }^{18}$ Nikolova 1983.
} 
Swoją polemiczną twórczością wywarł wielki wpływ na bułgarską inteligencję w latach czterdziestych i pięćdziesiątych XIX wieku. Znany jest przede wszystkim jako przeciwnik tzw. fanariotó $w^{19}$, autor wymierzonych przeciwko greckiemu duchowieństwu dialogów. Z kolei Emanuel Waskidowicz był nauczycielem języka greckiego i cerkiewnosłowiańskiego, a w końcu także bułgarskiego, tłumaczem oraz znanym działaczem oświatowym. Początkowo był zwolennikiem tzw. hellenizmu, z czasem, pod wpływem toczonych w kręgach inteligencji polemik, stał się orędownikiem nowego kształtu kultury odradzającej się Bułgarii.

Bozweli i Waskidowicz zamieścili w swojej encyklopedii wybór 20 bajek. Były to zupełnie inne teksty niż w podręczniku Berona, więc uczniowie zapoznać się mogli z kolejnymi, nowymi dla nich dziełami greckiego bajkopisarza ${ }^{20}$.

Zarówno książka Berona, jak i Słowianobułgarskie wychowanie dzieci były wielokrotnie wznawiane i powszechnie używane w powstających coraz liczniej szkołach, toteż obie w ogromnym stopniu przyczyniły się do popularyzacji utworów Ezopa.

Do tekstów greckiego bajkopisarza sięgnął też Neofit Rylski, jeden z najbardziej cenionych intelektualistów i nauczycieli, autor pierwszej gramatyki języka bułgarskiego. Dokonał on w latach 30. XIX wieku przekładu aż 151 bajek i biografii Ezopa według Maksyma Planudesa, które wprawdzie nie ukazały się drukiem, ale znali je uczniowie Neofita z dwu ważnych ośrodków intelektualnych tamtych czasów - Kopriwszticy i Samokowa. Darzący głębokim szacunkiem swojego nauczyciela, młodzi Bułgarzy chętnie przepisywali jego rękopiśmienne utwory, przyczyniając się do ich rozpowszechnienia na terenie całego kraju. Pamiętać bowiem należy, że w tym czasie na terenie Bułgarii nie działała jeszcze żadna drukarnia, a książki wydawano najczęściej w Wenecji, Serbii lub Rumunii, zatem popularność rękopiśmiennych kopii wciąż była duża. Przekład Neofita Rylskiego znacznie różni się od poprzednich, gdyż reprezentuje on zupełnie inny pogląd na temat rodzącej się bułgarszczyzny literackiej, próbując pogodzić nowsze tendencje do intelektualizacji gwar z językiem tradycji piśmienniczej.

Kolejnymi tłumaczami Ezopa na język bułgarski byli Petko Sławejkow (1852) i Rajno Popowicz (1854). Sławejkow zajmował się thumaczeniem z greki zanim odważył się pisać własne utwory poetyckie, w zasadzie obce dotąd bułgarskiej tradycji. Jego zbiór bajek Ezopa został zatytułowany Басненик ( $B a-$ jecznik) i był jedną z pierwszych książek stanowiących lekturę uzupełniającą dla szkół. Do dzisiaj książki tego typu noszą nazwę учебни помагала (Ротосе nauczania). Rajno Popowicz, który sam siebie określał mianem nauczyciela hellenogreckiego, w swoim zbiorze bajek wydanym w Belgradzie zamieścił 180 utworów, ale tylko 151 z nich określił jako Ezopowe. Są to te same utwory, które

\footnotetext{
${ }^{19}$ Fanariotami nazywano wpływowych Greków, wrogów bułgarskiego odrodzenia, nazwanych tak od dzielnicy Konstantynopola Fanar, gdzie mieściła się siedziba patriarchatu.

${ }^{20}$ Nikolova 1995.
} 
wcześniej tłumaczył Neofit Rylski, stąd do dziś trwa dyskusja na temat pierwowzoru przekładu Popowicza ${ }^{21}$.

Popularność utworów Ezopa zrodziła w Bułgarii duże zainteresowanie bajkami. W latach pięćdziesiątych XIX w. powstały pierwsze przekłady bajek Iwana Kryłowa i Jeana de La Fontaine'a (nota bene one również wyszły spod pióra Petka Sławejkowa). Po wyzwoleniu Bułgarii w 1878 r. wzrosło zainteresowanie rodzimym folklorem i twórczością ludową. W kręgu zainteresowań pisarzy znalazły się zatem także bajki rodzime, coraz chętniej spisywane i katalogowane. W tym samym czasie swoje utwory drukować zaczął pierwszy bułgarski bajkopisarz, Stojan Michajłowski. Kolejnymi przekładami i wydaniami utworów Ezopa zajęli się natomiast naukowcy, filolodzy z Uniwersytetu w Sofii i Bułgarskiej Akademii Nauk, Aleksander Bałabanow i Todor Sarafow. Powołanie tych dwu instytucji naukowych pod koniec XIX wieku oznaczało także początek filologii klasycznej w Bułgarii.

\section{BIBLIOGRAFIA}

Aretov 1995: Аретов Н., Българското Възраждане и Европа, София 1995.

Beron 1824: Берон П., Букваръ с различни поучения, wydanie fototypiczne, София 1824.

Dinekov 1990: Динеков П., Български фолклор, София 1990.

Ničev 1963: Ничев А., Софрониевият превод на Езоповите басни, „Годишник на СУ”, Филологически факултет, 1963, кн. 56, 10-114.

Nikolova 1995: Николова Ю., Баснята във възрожденските учебници, w: Училищната книжнина в България през ХІХ в., съст. А. Илиева, Пловдив 1995.

Nikolova 1983: Николова Ю., Езоповите басни и тяхното разпространение в българската възрожденска книжнина, „Литературна мисъл” 1983, кн. 11, 30-45.

Nikolova 2006: Николова Н., Билингвизмът в българските земи през XV-XIX век, Шумен 2006.

Solak 2009: Solak E., Znaki szczególne. Językowe i wokóljęzykowe problemy bułgarskiego Odrodzenia, Kraków 2009.

Walczak-Mikołajczakowa 2009: Walczak-Mikołajczakowa M., Bułgarski Ezop, Poznań 2009.

\section{BULGARIAN TRANSLATIONS OF EZOP'S FAIRY TALES \\ AND THEIR ROLE IN SHAPING A REVIVED SOCIETY IN $19^{\text {TH }}$ CENTURY}

Sum mary

Ezop's fairy tales were translated into Bulgarian only at the beginning of the $19^{\text {th }}$ century, that is during the so called National Revival. They quickly gained popularity, and their choice was included in the first textbook for secular schools. Due to their moralizing content, subsequent authors of textbooks continued to translate the fairy tales and incorporated them into their compendia as mandatory reading. Given the fact this was the case at the time when efforts were made to create a new, conscious and educated society which, after liberation from Turkish captivity, would be capable of organizing a modern state, the role of these tales in shaping appropriate attitudes would seem invaluable. One can not ignore the fact that, by being a widely known and widely read lecture, Ezop's fairy tales contributed to the popularization of the new shape of Bulgarian language, which in $19^{\text {th }}$ century left the Church Slavonic patterns.

\footnotetext{
${ }^{21}$ Walczak-Mikołajczakowa 2009: 91-100.
} 